\title{
Substituted quinolinones. Part 17: Some nucleophilic reactions with 4-hydroxy-1-methyl-3-[(2-oxo-2H-chromen-3-yl)carbonyl]quinolin- 2(1H)-one
}

\author{
MOHAMED ABASS ${ }^{\mathrm{a}, *}$, EL-HUSSAIN A MOHAMED ${ }^{\mathrm{a}}$, AISHA S MAYAS ${ }^{\mathrm{b}}$ and \\ AKRAM H IBRAHIM ${ }^{c}$ \\ a Department of Chemistry, Faculty of Education, Ain Shams University, Roxy, Heliopolis 11757, Cairo, Egypt \\ b Department of Chemistry, Faculty of Education, Sana'a University, Sana'a, Yemen \\ ${ }^{\mathrm{c}}$ Curriculum Development Center, Ministry of Education, Ramsis 13411 Cairo, Egypt \\ e-mail: m.abass@chemist.com
}

MS received 8 November 2011; revised 4 April 2012; accepted 26 April 2012

\begin{abstract}
The reactivity of 4-hydroxy-1-methyl-3-[(2-oxo-2H-chromen-3-yl)carbonyl]-quinolin-2(1H)-one (2), as a new asymmetric diheterocyclic ketone, towards different nucleophilic reagents, was examined. The reaction of the ketone $\mathbf{2}$ with hydrazine led to pyrazolinone $\mathbf{5}$, and excess of hydrazine pyrazolinopyrazole 7 was obtained. Treatment of the ketone $\mathbf{2}$ with 2,2-dimethoxyethanamine gave pyrrolocoumarin 12, while cyanoguanidine afforded pyrimidinone $\mathbf{1 5}$. Under PTC conditions, the ketone $\mathbf{2}$ was reacted with chloroacetonitrile, diethyl malonate, ethyl cyanoacetate, malononitrile, and cyanoacetamide to give coumarinyl furoquinoline 18, pyranoquinolines 20a, 20b, 21, and benzonaphthyridine 22, respectively.
\end{abstract}

Keywords. Quinolinone; coumarin; ketones; nucleophilic heterocyclization; PTC.

\section{Introduction}

The coumarin derivatives are representative of the lactones which have well-known pharmaceutical applications such as antimicrobial, ${ }^{1-4}$ cytotoxic activity against tumour cells and treatment of cancer $^{5,6}$ and significant value of anticoagulation potency drugs such as Warfarin. ${ }^{7-9}$ In addition, coumarin derivatives constitute an important class of organic fluorescent dyes with considerable interest for widespread application as sensitive fluorescent. ${ }^{10,11}$ On the other hand, quinolin-2-ones reveal important medicinal applications. For example, some quinolin-2-ones showed potential antidepressant, sedative and anti-Parkinson activities, ${ }^{12}$ antimicrobial activity, ${ }^{13}$ antifungal activity, ${ }^{14}$ inhibitory activity against HIV-1 Reverse Transcriptase, ${ }^{15}$ inhibitory activity against cyclin-dependent kinase 5 (CDK5), ${ }^{16}$ antiparasitic and antischistosomal activity. ${ }^{17-20}$ The above interesting biological application of both coumarin and quinolin-2-one derivatives invoked our attention to synthesize new heterocyclic compounds combining quinolin-2-one and coumarin moieties in one molecular-frame. This comes as a part of our research program directed at the synthesis of

*For correspondence new heterocyclic 3-substituted quinolinone derivatives of expected biological activity.

\section{Experimental}

\subsection{General}

Melting points were determined in open capillary tubes on a digital Stuart SMP3 apparatus. IR spectra were taken on a Perkin-Elmer FT-IR 1650, using samples in $\mathrm{KBr}$ disks. ${ }^{1} \mathrm{H}$ NMR spectra were recorded on Varian Gemini-200 NMR-spectrometer (200 MHz), using DMSO- $d_{6}$ as solvents and TMS as internal reference. Mass spectra were determined on a Shimadzu GC-MSQP 1000 EX mass spectrometer by direct inlet, operating at $70 \mathrm{eV}$. Elemental microanalyses were performed on a Perkin Elmer CHN-2400 Analyzer at the Microanalytical Center, Cairo University. All reactions were monitored by thin-layer chromatography (TLC) on $0.2 \mathrm{~mm}$ silica gel F-254 (Merck) plates, using UV light $(254$ and $366 \mathrm{~nm})$ for detection.

\subsection{4-Hydroxy-1-methyl-3-[(2-oxo-2H-chromen-} 3-yl)carbonyl]quinolin-2(1H)-one (2)

This compound was prepared according to the method described in the literature. ${ }^{21}$ 
2.3 4-Hydroxy-3-[4-(2-hydroxybenzylidene)-5-oxo4,5-dihydro-1H-pyrazol-3-yl]-1-methylquinolin-2(1H)one (5)

To a suspension of the compound $2(0.7 \mathrm{~g}, 2 \mathrm{mmol})$, in ethanol $(20 \mathrm{~mL})$, was added hydrazine hydrate $(0.1 \mathrm{~mL}$, $2 \mathrm{mmol}, 100 \%)$. Then, the mixture was heated under reflux for $3 \mathrm{~h}$. The solution so formed was cooled to room temperature to give a crystalline precipitate which was filtered and recrystallized from DMF to give the pyrazole 5; yield $75 \%$; mp $245-246^{\circ} \mathrm{C}$. Literature ${ }^{22}$ m.p. $241-242^{\circ} \mathrm{C}$.

\subsection{4-Hydroxy-3-[4-(2-hydroxyphenyl)-1,4,5, 6-tetrahydropyrazolo[3,4-c]pyrazol-3-yl]-1- methylquinolin-2(1H)-one (7)}

2.4a Procedure A: To a suspension of the compound 5 (0.72 g, $2 \mathrm{mmol})$, in DMF ( $15 \mathrm{~mL})$, hydrazine hydrate $(0.1 \mathrm{~mL}, 2 \mathrm{mmol})$ was added and heated under reflux for $2 \mathrm{~h}$. After cooling, the crystalline material that formed was filtered and recrystallized from DMF to give the pyrazolopyrazole 7 ; yield $70 \% ; \mathrm{mp}>300^{\circ} \mathrm{C}$. IR (KBr), v $\left(\mathrm{cm}^{-1}\right)$ : 3333-2625 (H-bonded O-H + $\mathrm{N}-\mathrm{H}), 1644\left(\mathrm{C}=\mathrm{O}_{\text {quinolone }}\right), 1611(\mathrm{C}=\mathrm{N}) .{ }^{1} \mathrm{H}$ NMR $\left(200 \mathrm{MHz}, \mathrm{DMSO}-d_{6}\right): \delta=2.75\left(\mathrm{~s}, 1 \mathrm{H}, \mathrm{CH}_{\text {pyrazoline }}\right)$, 3.74 (s, 3H, $\mathrm{NCH}_{3}$ ), 7.35-8.09 (m., 8H, $\mathrm{H}_{\text {arom. }}$ ), 8.40 (b, $\left.1 \mathrm{H}, \mathrm{NH}_{\text {pyrazole }}\right), 9.20$ (b, $\left.1 \mathrm{H}, \mathrm{NH}_{\text {pyrazole }}\right), 9.40$ (b, $\left.1 \mathrm{H}, \mathrm{NH}_{\text {pyrazoline }}\right) 11.00\left(\mathrm{~s}, 1 \mathrm{H}, \mathrm{OH}_{\text {phenolic }}\right), 13.8(\mathrm{~s}, 1 \mathrm{H}$, $\left.\mathrm{OH}_{\text {quinolinone }}\right) . \mathrm{MS}(\mathrm{m} / \mathrm{z} ; \%)=375(10)\left(\mathrm{M}^{+\cdot}\right), 376$ $(\mathrm{M}+1 ; 2.8), 377$ (M+2; 3.2), 364 (6.3), 363 (26.4), 361 (100), 228 (12.7), 200 (19.9), 188 (19.6), 187 (14.0), 176 (16.2), 175 (86.3), 147 (23.4), 134 (23.7), 104 (26.3), 77 (50.9), 63 (12.9), 51 (26.7). Anal. Calcd. (\%) for $\mathrm{C}_{20} \mathrm{H}_{17} \mathrm{~N}_{5} \mathrm{O}_{3}$ (375.39): C, 63.99; $\mathrm{H}, 4.56 ; \mathrm{N}, 18.66$. Found (\%): C, 64.10; H, 4.40; N, 18.60 .

2.4b Procedure B: To a suspension of the compound $2(0.35 \mathrm{~g}, 1 \mathrm{mmol})$, in ethanol $(10 \mathrm{~mL})$, was added hydrazine hydrate $(0.1 \mathrm{~mL}, 2 \mathrm{mmol})$. The mixture was heated under reflux for $4 \mathrm{~h}$ and the solid precipitate that obtained was filtered, and crystallized from DMF to give the pyrazolopyrazole 7 ; yield $78 \%$.

\subsection{3-(4-Hydroxy-1-methyl-2-oxo-1,}

2-dihydroquinolin-3-yl)-1-(methoxymethyl-

chromeno[3,4-c]pyrrol-4(2H)-one (12)

A mixture of the compound $2(0.7 \mathrm{~g}, 1 \mathrm{mmol})$ and 2,2dimethoxyethanamine $(0.5 \mathrm{~mL}, 4 \mathrm{mmol})$, in toluene was heated under reflux $4 \mathrm{~h}$. The solvent was evaporated to dryness and the residue was treated with cold methanol $(5 \mathrm{~mL})$ to obtain a solid powder, which was washed several times with diethyl ether and crystallized from DMSO to give the compound 12; yield 65\%; mp 200 $202^{\circ} \mathrm{C}$. IR $(\mathrm{KBr}), v\left(\mathrm{~cm}^{-1}\right): 3420,3250$, (H-bonded O$\mathrm{H}+\mathrm{N}-\mathrm{H}), 1723\left(\mathrm{C}=\mathrm{O}_{\text {Coumarin }}\right), 1639\left(\mathrm{C}=\mathrm{O}_{\text {quinolone }}\right)$, 1188, 1130, 1077(C-O). ${ }^{1} \mathrm{H}$ NMR (200 MHz, DMSO$\left.d_{6}\right): \delta=3.30\left(\mathrm{~s}, 3 \mathrm{H}, \mathrm{NCH}_{3}\right), 3.35\left(\mathrm{~s}, 3 \mathrm{H}, \mathrm{OCH}_{3}\right), 4.60$ (s, 2H, $\mathrm{CH}_{2} \mathrm{OCH}_{3}$ ), 7.23-8.15 (s, 8H, $\mathrm{H}_{\text {arom }}$ ) $)$ 13.17(s, $1 \mathrm{H}, \mathrm{NH}), 14.52(\mathrm{~s}, 1 \mathrm{H}, \mathrm{OH}) . \mathrm{MS}(\mathrm{m} / \mathrm{z} ; \%)=402(13)$ $\left(\mathrm{M}^{+} \cdot\right), 403(\mathrm{M}+1 ; 3.3), 404(\mathrm{M}+2 ; 2.5), 359$ (2.6), 330 (14.3), 104 (4.8), 75 (100), 51 (4.6). Anal. Calcd. (\%) for $\mathrm{C}_{23} \mathrm{H}_{18} \mathrm{~N}_{2} \mathrm{O}_{5}(402.41)$ : C, 68.65; H, 4.47; N, 6.96. Found (\%): C, 68.60; H, 4.50; N, 6.70.

2.6 2-(N-Cyanoimino)-4-(4-hydroxy-1-methyl-2-oxo1,2-dihydroquinolin-3-yl)-5-(2-hydroxybenzylidene)1,2-dihydropyrimidin-6(5H)-one (15)

A mixture of compound $2(0.7 \mathrm{~g}, 2 \mathrm{mmol})$, cyanoguanidine hydrochloride $(0.25 \mathrm{~g}, 2 \mathrm{mmol})$ and $(0.1 \mathrm{~mL})$, fine powdered potassium hydroxide $(0.56 \mathrm{~g}, 10 \mathrm{mmol})$, in ethanol $(30 \mathrm{~mL})$, was heated under reflux for $3 \mathrm{~h}$. Afterwards, the mixture was left to cool at room temperature, poured onto cold water and then acidified with ice-cold dilute hydrochloric acid till complete precipitation. The solid precipitate so obtained was filtered, washed with water and crystallized from DMF, affording the pyrimidine 15 ; yield $56 \%$; mp $220-221^{\circ} \mathrm{C}$. IR $(\mathrm{KBr}), v\left(\mathrm{~cm}^{-1}\right): 3424$ (H-bonded $\left.\mathrm{OH}, \mathrm{NH}\right), 2198$ $(\mathrm{C} \equiv \mathrm{N}), 1652\left(\mathrm{C}=\mathrm{O}_{\text {quinolone }}\right), 1637\left(\mathrm{C}=\mathrm{O}_{\text {pyrimidone }}\right), 1570$ $(\mathrm{C}=\mathrm{N}) \cdot{ }^{1} \mathrm{H}$ NMR $\left(200 \mathrm{MHz}, \mathrm{DMSO}-d_{6}\right): \delta=3.53$ $\left(\mathrm{s}, 3 \mathrm{H}, \mathrm{NCH}_{3}\right), 6.80\left(\mathrm{~s}, 1 \mathrm{H}, \mathrm{H}_{\text {olefin }}\right), 6.99-8.00(\mathrm{~m}, 8 \mathrm{H}$, $\left.\mathrm{H}_{\text {arom }}\right), 10.40$ (s, $\left.1 \mathrm{H}, \mathrm{NH}\right), 11.35$ (s, 1H, $\left.\mathrm{OH}_{\text {phenol }}\right), 13.85$ (s, $\left.1 \mathrm{H}, \mathrm{OH}_{\text {quinolone }}\right) . \mathrm{MS}(\mathrm{m} / \mathrm{z} ; \%)=413(6.6)\left(\mathrm{M}^{+\cdot}\right)$, 414 (M+1; 2.2), 399 (28.5), 371(100), 227 (10.5), 185 (30.0), 159 (32.1), 146 (8.2), 143 (13.4), 55 (50.6). Anal. Calcd. (\%) for $\mathrm{C}_{22} \mathrm{H}_{15} \mathrm{~N}_{5} \mathrm{O}_{4}$ (413.40): $\mathrm{C}, 63.92 ; \mathrm{H}$, $3.66 ; \mathrm{N}, 16.94$. Found (\%): C, 63.90; H, 3.60; N, 16.60.

\subsection{PTC-Reaction of the ketone $\mathbf{2}$ with active methylene compounds}

To a mixture of compound $2(0.7 \mathrm{~g}, 2 \mathrm{mmol})$, TBAB $(0.25 \mathrm{~g}, 1 \mathrm{mmol})$ and potassium carbonate $(1.38 \mathrm{~g}$, $10 \mathrm{mmol})$, in DMF $(20 \mathrm{~mL})$, was added $2 \mathrm{mmol}$ of the proper active methylene reagent viz; chloroacetonitrile $(0.15 \mathrm{~mL})$, diethyl malonate $(0.3 \mathrm{~mL})$, ethyl cyanoacetate $(0.22 \mathrm{~mL})$, malononitrile $(0.14 \mathrm{~g})$, and cyanoacetamide $(0.17 \mathrm{~g})$. The mixture was heated under reflux for $4 \mathrm{~h}$. The mixture was filtered off, while hot, and the filtrate was poured onto cold water and then acidified with dilute hydrochloric acid. The solid precipitate so obtained was filtered and crystallized from DMF. 
2.7a 5-Methyl-4-oxo-3-(2-oxo-2H-chromen-3-yl)-4, 5- dihydrofuro[3,2-c]quinoline-2-carbonitrile (18): Yield 73\%; mp 270-2 ${ }^{\circ} \mathrm{C}$. IR (KBr), v $\left(\mathrm{cm}^{-1}\right): 3082,2957$, $2196(\mathrm{C} \equiv \mathrm{N}), 1724\left(\mathrm{C}=\mathrm{O}_{\text {coumarin }}\right), 1642\left(\mathrm{C}=\mathrm{O}_{\text {quinolone }}\right)$, $1602(\mathrm{C}=\mathrm{C}) .{ }^{1} \mathrm{H}$ NMR $\left(200 \mathrm{MHz}, \mathrm{DMSO}-d_{6}\right): \delta=3.48$ (s, 3H, $\left.\mathrm{CH}_{3}\right), 7.25\left(\mathrm{t}, 1 \mathrm{H}, 8-\mathrm{H}_{\text {furoquinoline }}\right), 7.38-7.45(\mathrm{~m}$, $\left.3 \mathrm{H}, \mathrm{H}_{\text {arom }}\right), 7.65$ (t, $\left.1 \mathrm{H}, \mathrm{H}_{\text {arom }}, 7-\mathrm{H}_{\text {coumarin }}\right), 7.78-7.92$ $\left(\mathrm{m}, 3 \mathrm{H}, \mathrm{H}_{\text {arom }}\right), 8.05\left(\mathrm{~s}, 1 \mathrm{H}, 4-\mathrm{H}_{\text {coumarin }}\right) . \mathrm{MS}(\mathrm{m} / \mathrm{z} ; \%)=$ $368\left(\mathrm{M}^{+\cdot}\right)$ (100), $369(\mathrm{M}=1 ; 23), 370(\mathrm{M}+2 ; 2), 342$ (64), 340 (72), 324 (36), 314 (22), 195 (47), 175 (35),<smiles>Cn1c(=O)c(C(=O)CC(=O)O)c(O)c2ccccc21</smiles>

1<smiles>Cn1c(=O)c(C(=O)/C(=C/c2ccccc2O)C(=O)NN)c(O)c2ccccc21</smiles>

3

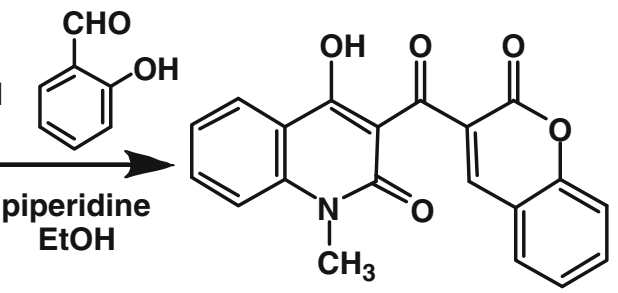

2

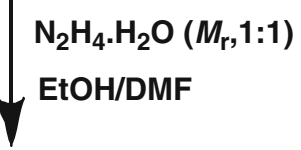

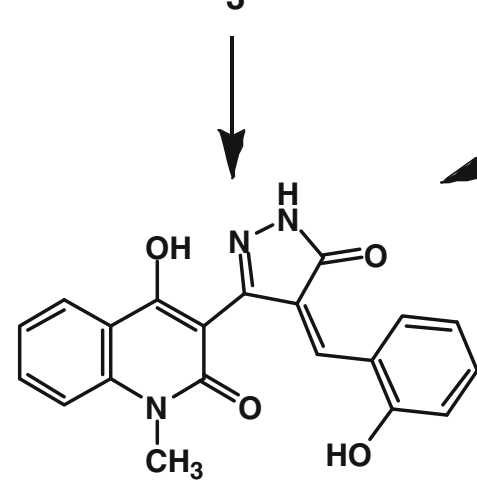

5

$$
\mathrm{N}_{2} \mathrm{H}_{4} \cdot \mathrm{H}_{2} \mathrm{O}
$$
EtOH/DMF<smiles>Cn1c(=O)c(-c2n[nH]c3c2C(c2ccccc2O)NN3)c(O)c2ccccc21</smiles>

Scheme 1. Synthesis of compound 2 and its reaction with hydrazine hydrate. 
174 (22), 169 (14), 160 (22), 149 (11), 90 (16), 89 (14), 72 (24), 69 (41). Anal. Calcd. (\%) for $\mathrm{C}_{22} \mathrm{H}_{12} \mathrm{~N}_{2} \mathrm{O}_{4}$ (368.08): C, 71.74; H, 3.28; N, 7.61. Found (\%): C, $72.10 ; \mathrm{H}, 3.30 ; \mathrm{N}, 7.50$.

2.7b Ethyl 6-methyl-2,5-dioxo-4-(2-oxo-2H-chromen3-yl)-5,6-dihydro-2H-pyrano[3,2-c]-quinoline-3-carboxylate (20a): Yield $66 \% ; \mathrm{mp}>300^{\circ} \mathrm{C}$. IR $(\mathrm{KBr}), v$ $\left(\mathrm{cm}^{-1}\right)$ : 3072, 2856, $1710\left(\mathrm{C}=\mathrm{O}_{\text {ester }}\right), 1693\left(\mathrm{C}=\mathrm{O}_{\text {pyrone }}\right)$,
$1642\left(\mathrm{C}=\mathrm{O}_{\text {coumarin }}\right), 1629\left(\mathrm{C}=\mathrm{O}_{\text {quinolone }}\right) .{ }^{1} \mathrm{H}$ NMR $\left(200 \mathrm{MHz}, \mathrm{DMSO}-d_{6}\right): \delta=1.24\left(\mathrm{t}, 3 \mathrm{H}, \mathrm{OCH}_{2} \mathrm{CH}_{3}\right)$, $3.97\left(\mathrm{~s}, 3 \mathrm{H}, \mathrm{NCH}_{3}\right), 4.23\left(\mathrm{q}, 2 \mathrm{H}, \mathrm{CH}_{2} \mathrm{CH}_{3}\right), 7.36-$ 7.88 (m, 8H, $\left.\mathrm{H}_{\text {arom. }}\right), 8.16$ (s, $\left.1 \mathrm{H}, \mathrm{C} 4-\mathrm{H}_{\text {coumarin }}\right)$. MS $(\mathrm{m} / \mathrm{z} ; \%)=443\left(\mathrm{M}^{+}\right)(6.8), 444(\mathrm{M}+1 ; 2.1), 362$ (15.2), 341 (2.7), 342 (22.6), 343 (8.6), 324 (5.4), 307 (6.3), 262 (11.7), 215 (11.5), 175 (26.3), 144 (100), 104 (26.3), 71 (71.4), 55 (74.2), 57 (94.1). Anal. Calcd. (\%) for $\mathrm{C}_{25} \mathrm{H}_{17} \mathrm{NO}_{7}$ (443.42): $\mathrm{C}, 67.72 ; \mathrm{H}, 3.86 ; \mathrm{N}$, 3.16. Found (\%): C, 67.60; H, 3.80; N, 3.10.<smiles>Cn1c(=O)c(C(=O)c2cc3ccccc3oc2=O)c(O)c2ccccc21</smiles>

2

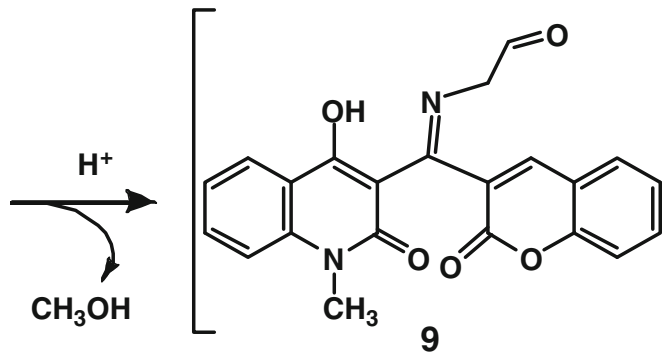<smiles>Cn1c(=O)c(C2=C3C(=O)Oc4ccccc4C3C(C=O)N2)c(O)c2ccccc21</smiles><smiles>Cn1c(=O)c(C2=C3C(=O)Oc4ccccc4C3/C(=C\O)N2)c(O)c2ccccc21</smiles>

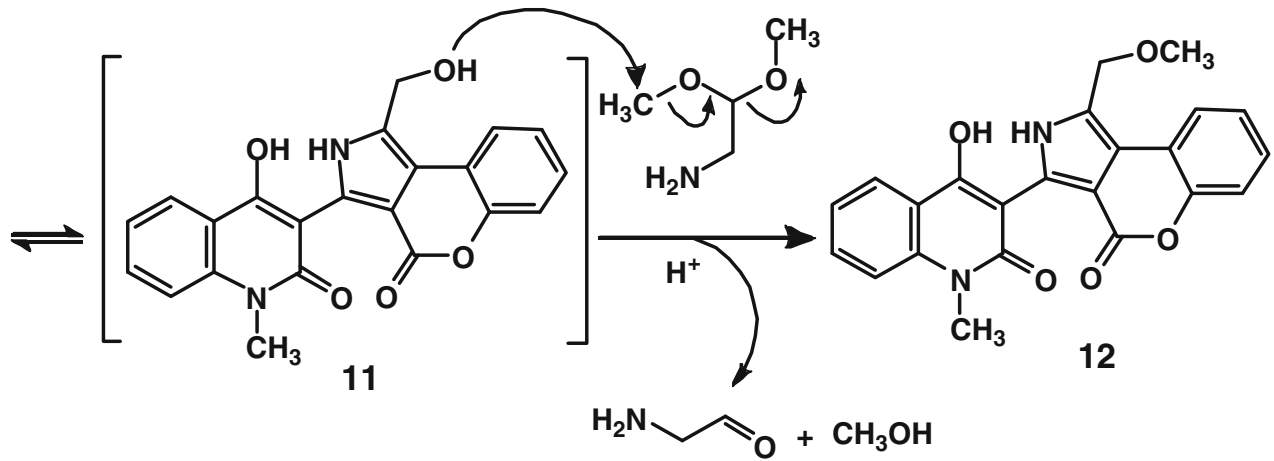

Scheme 2. A mechanistic pathway for formation of compound 12 . 
2.7c 6-Methyl-2,5-dioxo-4-(2-oxo-2H-chromen-3-yl)5,6-dihydro-2H-pyrano[3,2-c]quinoline-3-carbonitrile (20b): Yield $63 \% ; \mathrm{mp}>300^{\circ} \mathrm{C}$. IR $(\mathrm{KBr}), v\left(\mathrm{~cm}^{-1}\right)$ : 3076, $2203 \quad(\mathrm{C} \equiv \mathrm{N}), \quad 1703 \quad(\mathrm{C}=\mathrm{O} \quad$ coumarin $), \quad 1969$ $\left(\mathrm{C}=\mathrm{O}_{\text {pyrone }}\right), 1633\left(\mathrm{C}=\mathrm{O}_{\text {quinolone }}\right) .{ }^{1} \mathrm{H}$ NMR $(200 \mathrm{MHz}$, DMSO- $\left.d_{6}\right): \delta=3.58\left(\mathrm{~s}, 3 \mathrm{H}, \mathrm{NCH}_{3}\right), 7.31(\mathrm{t}, J=8 \mathrm{~Hz}$, $2 \mathrm{H}, \mathrm{C} 8-\mathrm{H}), 7.50$ (d, $J=8 \mathrm{~Hz}, 2 \mathrm{H}, \mathrm{C} 7-\mathrm{H}), 7.66(\mathrm{t}, J=$ $8 \mathrm{~Hz}, 2 \mathrm{H}, \mathrm{C} 6-\mathrm{H}), 8(\mathrm{~d}, J=8 \mathrm{~Hz}, \mathrm{C} 5-\mathrm{H}), 8.56(\mathrm{~s}, 1 \mathrm{H}$, C4- $\left.\mathrm{H}_{\text {coumarin }}\right)$. MS $(\mathrm{m} / \mathrm{z} ; \%)=396\left(\mathrm{M}^{+\cdot}\right)(5.0), 397$ (M+1; 1.9), 395 (28.3), 285 (24.4), 284 (24.6), 238 (48.6), 239 (38.6), 217 (48.9), 206 (43.6), 186 (28.9), 169 (33.4), 159 (62.6), 142 (33.7), 119 (19.8), 117 (71.0), 115 (23.8), 90 (23.8), 60 (100), 53 (33.6). Anal. Calcd. (\%) for $\mathrm{C}_{23} \mathrm{H}_{12} \mathrm{~N}_{2} \mathrm{O}_{5}$ (396.36): $\mathrm{C}, 69.70 ; \mathrm{H}, 3.05$; N, 7.07. Found (\%): C, 69.60; H, 3.10; N, 7.20.

2.7d 2-Imino-6-methyl-5-oxo-4-(2-oxo-2H-chromen3-yl)-5, 6-dihydro-2H-pyrano[3,2-c]quinoline-3-carbonitrile (21): Yield 84\%; mp 291-2 ${ }^{\circ} \mathrm{C}$. IR (KBr), v $\left(\mathrm{cm}^{-1}\right): 3396 \quad(\mathrm{NH}), \quad 2925, \quad 2201 \quad(\mathrm{C} \equiv \mathrm{N}), \quad 1710$ $\left(\mathrm{C}=\mathrm{O}_{\text {coumarin }}\right), 1640 \quad\left(\mathrm{C}=\mathrm{O}_{\text {quinolone }}\right), \quad 1601(\mathrm{C}=\mathrm{N}) .{ }^{1} \mathrm{H}$ NMR $\left(200 \mathrm{MHz}, \mathrm{DMSO}-d_{6}\right): \delta=3.70\left(\mathrm{~s}, 3 \mathrm{H}, \mathrm{NCH}_{3}\right)$, 7.22-7.57 (m., 8H, $\mathrm{H}_{\text {arom. }}$ ), 8.10 (s, $1 \mathrm{H}, \mathrm{C} 4-\mathrm{H}_{\text {coumarin }}$ ), $8.75(\mathrm{~b}, 1 \mathrm{H}, \mathrm{NH}) . \mathrm{MS}(\mathrm{m} / \mathrm{z} ; \%)=395\left(\mathrm{M}^{+}\right)$(56.4), 396 (M+1; 14.3), 266 (23.2), 265 (22.4), 260 (16.3), 233 (14.4), 232 (16.6), 168 (20.3), 141 (19.5), 115 (14.3), 111 (11.2), 82 (21.5), 73 (31.7), 68 (23.8), 60 (100), 59 (87.7), 57 (28.3). Anal. Calcd. (\%) for $\mathrm{C}_{23} \mathrm{H}_{13} \mathrm{~N}_{3} \mathrm{O}_{4}$ (395.38): C, 69.87; H, 3.31; N, 10.63 . Found (\%): C, 69.80; H, 3.30; N, 10.60 .

2.7e 6-Methyl-2,5-dioxo-4-(2-oxo-2H-chromen-3-yl)1,2,5,6-tetrahydrobenzo[h]-1,6-naphthyridine-3-carbonitrile (22): Yield 59\%; mp 288-9 ${ }^{\circ} \mathrm{C}$. IR ( $\left.\mathrm{KBr}\right), v$ $\left(\mathrm{cm}^{-1}\right): 3424(\mathrm{NH}), 3061,2938,2198(\mathrm{C} \equiv \mathrm{N}), 1722$ $\left(\mathrm{C}=\mathrm{O}_{\text {coumarin }}\right), 1644\left(\mathrm{C}=\mathrm{O}_{\text {pyridone }}\right), 1637\left(\mathrm{C}=\mathrm{O}_{\text {quinolone }}\right)$. ${ }^{1} \mathrm{H}$ NMR $\left(200 \mathrm{MHz}, \mathrm{DMSO}-d_{6}\right): \delta=3.44(\mathrm{~s}, 3 \mathrm{H}$, $\left.\mathrm{NCH}_{3}\right), 7.10-7.81$ (m, 8H, Harom.), 7.99 (s, 1H, C4-<smiles></smiles>

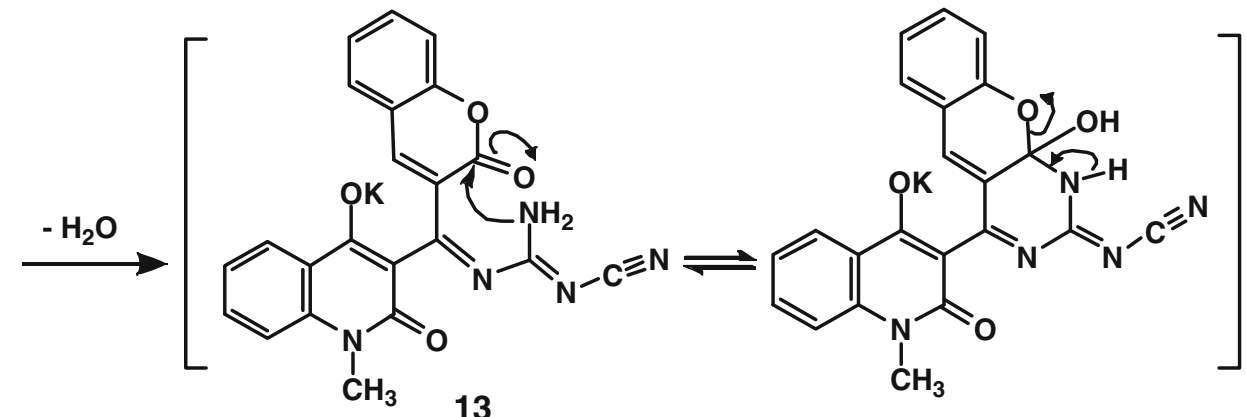<smiles>CCOC1=NC(=NC#N)N=C(c2c(O)c3ccccc3n(C)c2=O)C1=Cc1ccccc1OCCO</smiles>

Scheme 3. A mechanistic pathway for formation of compound 15 . 
$\left.\mathrm{H}_{\text {coumarin }}\right), 8.30(\mathrm{~s}, 1 \mathrm{H}, \mathrm{NH}) . \mathrm{MS}(\mathrm{m} / \mathrm{z} ; \%)=395\left(\mathrm{M}^{+\cdot}\right)$ (3.5), $396(\mathrm{M}+1$; 1), 354 (3.8), 238 (21.2), 239 (12.2), 218 (21.4), 217 (13.6), 206 (21.9), 186 (18.1), 169 (12.8), 159 (21.6), 142 (43.2), 119 (14.3), 117 (73.4), 115 (23.2), 90 (15.2), 61 (100), 53 (33.4). Anal. Calcd. (\%) for $\mathrm{C}_{23} \mathrm{H}_{13} \mathrm{~N}_{3} \mathrm{O}_{4}$ (395.38): $\mathrm{C}, 69.87 ; \mathrm{H}, 3.31 ; \mathrm{N}$, 10.63. Found (\%): C, 69.60; H, 3.20; N, 10.30.

\section{Results and discussion}

Some literature reports had cited important reactions of $\alpha$-pyrones with hydrazine derivatives in synthesis of pyrazolines. ${ }^{23}$ Accordingly, the reaction of the ketone 2 with hydrazine hydrate was carried out at equimolar ratio, to give pyrazolylquinolinone $\mathbf{5}$. This product may be afforded through intermediacy of the hydrazide 3 or the hydrazone 4 . Anyhow formation of the hydrazone intermediate $\mathbf{4}$ may lead to formation of the pyrazoloquinolinone $\mathbf{6}$ and/or the pyrazolylquinolinone $\mathbf{5}$ (scheme 1). Since pyrazolylquinolinone 5 was only separated from this reaction. This result led to assuming that the formation of the pyrazolylquinolinone $\mathbf{5}$ takes place via ring-opening ring closure (RORC) pathway. Moreover, the spectral and analytical data of the pyrazolylquinolinone $\mathbf{5}$ are coincident with data of a previously prepared authentic sample, using different synthetic route. ${ }^{22}$ The pyrazolopyrazole 7 was obtained, in $70 \%$ yield, when the pyrazolylquinolinone $\mathbf{5}$ was subjected to react with hydrazine hydrate, in DMF. The same compound was obtainable by treating the ketone $\mathbf{2}$ with excess of hydrazine hydrate. The structure of compound 7 was inferred from its analytical and spectral data. IR spectrum showed broad stretching band at $\tilde{v}$ 3333-2625, characteristic for H-bonded $\mathrm{O}-\mathrm{H}$ and $\mathrm{N}-\mathrm{H}, 1644$ due to $\mathrm{C}=\mathrm{O}$ of quinolin-2-one. ${ }^{1} \mathrm{H}$ NMR spectrum revealed a singlet peak at $\delta 2.75$ due to $\mathrm{C} 5-\mathrm{H}$ of pyrazolinopyrazole, a singlet peak at $\delta 3.74$ due to $\mathrm{N}-\mathrm{CH}_{3}$. In addition, five broad peaks, which disappeared on deutration with $\mathrm{D}_{2} \mathrm{O}$, were observed at $\delta$ 8.40, 9.20, 9.40 (NH groups), 11.00 and 13.80 (phenolic $\mathrm{OH}$ groups). Mass spectrum confirmed the proposed formula revealing a molecular ion peak at $\mathrm{m} / \mathrm{z} 375$ along with a base peak at 361 due $\left(\mathrm{M}^{+}-\mathrm{CH}_{3}\right)$ cation. In addition, a fragment appeared at $\mathrm{m} / \mathrm{z} 175$ characteristic for 4-hydroxy-1-methylquinolin-2-one cation.

The reaction of the ketone $\mathbf{2}$ with 2,2-dimethoxyethanamine was carried out in boiling toluene in order to obtain the corresponding Schiff's base. ${ }^{1} \mathrm{H}$ NMR spectrum of the product showed three singlet chemical shifts at $\delta 3.30$ due to $\left(\mathrm{NCH}_{3}\right), \delta 3.35$ attributed to three protons of $\left(\mathrm{OCH}_{3}\right)$, and $\delta 4.60$ due to two protons of $\left(\mathrm{CH}_{2} \mathrm{OMe}\right)$. The aromatic eight protons were observed as multiplet at $\delta 7.23-8.15$. The characteristic proton at position 4 of coumarin was absent. Two $\mathrm{D}_{2} \mathrm{O}$-exchangeable protons were noticed at

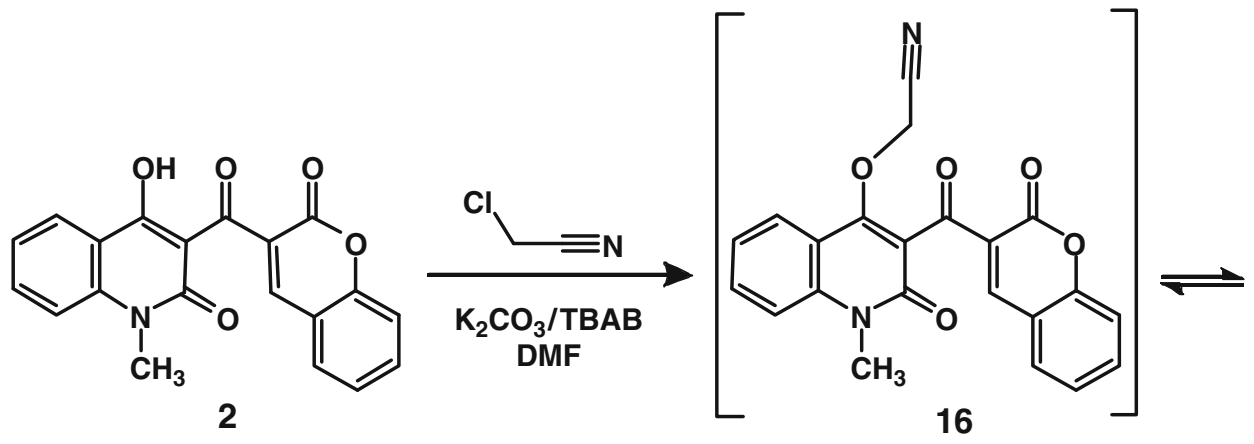

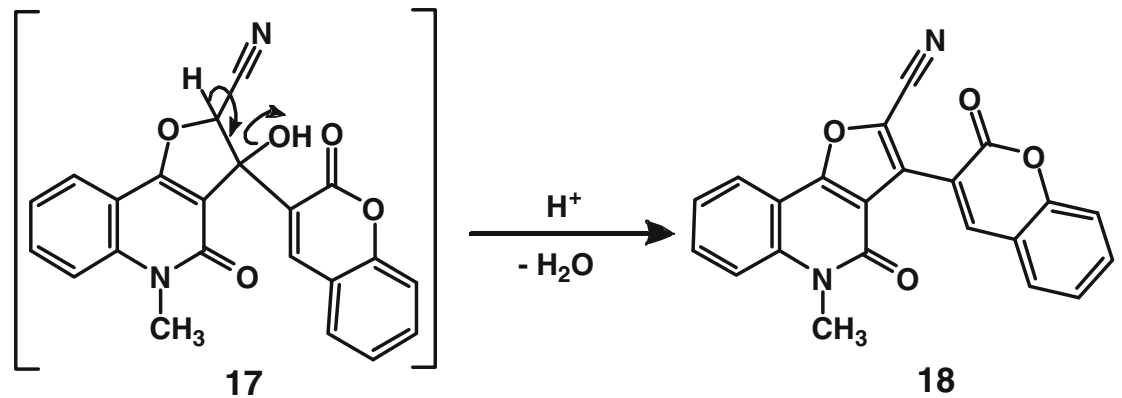

Scheme 4. Formation of chromenylfuro[3,2-c] quinoline derivative 18. 
$\delta 13.17$ and 14.52 due to $\mathrm{N}-\mathrm{H}$ and $\mathrm{O}-\mathrm{H}$, respectively. IR spectrum exhibited stretching bands at $\tilde{v} 3420$, and $3250 \mathrm{~cm}^{-1}$, due to $\mathrm{N}-\mathrm{H}$ and $\mathrm{O}-\mathrm{H}$. The absorption bands due to the carbonyl groups of coumarin, quinolinone moieties appeared at $\bar{v} 1723,1639 \mathrm{~cm}^{-1}$, respectively. Accordingly, the product was characterized as the quinolinylchromeno[3,4-c]pyrrole 12. The formation of the product is thought to pass through these consecutive steps; condensation, de-methanolysis, intramolecular Michael addition, and $\mathrm{S}_{\mathrm{N}} 2 O$-methylation of the presumed condensation intermediate (scheme 2).

Cyanoguanidine, as 1,3-nucleophile, was subjected to react with the ketone 2 , in the presence of potassium hydroxide. ${ }^{1} \mathrm{H}$ NMR spectrum of the product showed no indication for the proton, at position- 4 , of coumarin and revealed the following characteristic peaks at $\delta$ $3.53\left(\mathrm{~N}-\mathrm{CH}_{3}\right), 6.80$ (olefinic $\mathrm{C}-\mathrm{H}, 1 \mathrm{H}$ ), 6.99-8.00 (aromatic $\mathrm{C}-\mathrm{H}, 8 \mathrm{H}), 10.40(\mathrm{~N}-\mathrm{H}), 11.35(\mathrm{O}-\mathrm{H})$, and 13.85 $(\mathrm{O}-\mathrm{H})$. IR spectrum confirmed the disappearance of $\mathrm{C}=\mathrm{O}$ of coumarin nucleus and showed the following absorption bands at $\tilde{v} 3424(\mathrm{~N}-\mathrm{H}), 2198(\mathrm{C} \equiv \mathrm{N}), 1652$ $(\mathrm{C}=\mathrm{O}), 1637(\mathrm{C}=\mathrm{O}) \mathrm{cm}^{-1} \cdot{ }^{1} \mathrm{H}$ NMR and IR spectra proved opening of coumarin ring via an intramolecular nucleophilic tetrahedral addition in intermediate $\mathbf{1 3}$ and closure of pyrimidinone ring, leading to sodium enolate $\mathbf{1 4}$ which upon acidification afforded the product. Hence, the 4-quinolinylpyrimidine derivative $\mathbf{1 5}$ was characterized as the product of this reaction (scheme 3 ).

The reaction of chloroacetonitrile with the ketone $\mathbf{2}$, was carried out under phase transfer catalytic conditions (PTC), in the presence of potassium carbonate and
TBAB, in DMF. IR spectrum of the product demonstrated absorption band at $\tilde{v} 2196$ characteristic for $(\mathrm{C} \equiv \mathrm{N})$, in addition to $\tilde{v} 1724$ and $1642 \mathrm{~cm}^{-1}$ due to $(\mathrm{C}=\mathrm{O})$ of both coumarin and quinolin-2one, respectively. ${ }^{1} \mathrm{H}$ NMR revealed peaks at $\delta 7.25-7.92$ due to eight aromatic protons, in addition to a singlet peak at $\delta 8.05$ distinguishing proton at position 4 of coumarin. MS spectrum represented the molecular ion peak $\left(\mathrm{M}^{+\cdot}\right)$ at $\mathrm{m} / \mathrm{z} 368$ as the base peak $(I \%, 100)$, along with $\mathrm{M}+1$ at $369(23 \%)$, and $(\mathrm{M}+2)$ at $370(2 \%)$. These results are perfectly integrated with elemental microanalysis of the product and suggested that the 3-coumarinylfuro[3,2c]quinoline-2-carbonitrile derivative $\mathbf{1 8}$ is the product (scheme 4).

The reaction of the compound $\mathbf{2}$ with diethyl malonate was carried out, in DMF, under phase transfer catalysis (PTC) conditions, using potassium carbonate and tetrabutylammonium bromide (TBAB). PTC reaction technique was selected to prevent undesired $\alpha$-pyrone ring opening open which is expected on use of ordinary basic media, e.g., hydroxides or alkoxides. Under PTC conditions, ethyl 4-coumarinylpyranoquinoline-3-carboxylate 20a was obtained, in $66 \%$ yield (scheme 5). ${ }^{1} \mathrm{H}$ NMR spectrum of compound 20a confirmed the presence of signals owing to $\mathrm{OCH}_{2} \mathrm{CH}_{3}$ appeared as triplet at $\delta 1.24$ and quartet at $\delta 4.23$, in addition to a singlet peak at $\delta 8.16$ due to chemical shift of $\mathrm{C} 4-\mathrm{H}$ of coumarin. IR spectrum fortified the supposed structure of compound 20a where its spectrum showed characteristic bands at $\tilde{v}$ $1710,1693,1642 \mathrm{~cm}^{-1}$, due to $\mathrm{C}=\mathrm{O}$ of carboxylate,

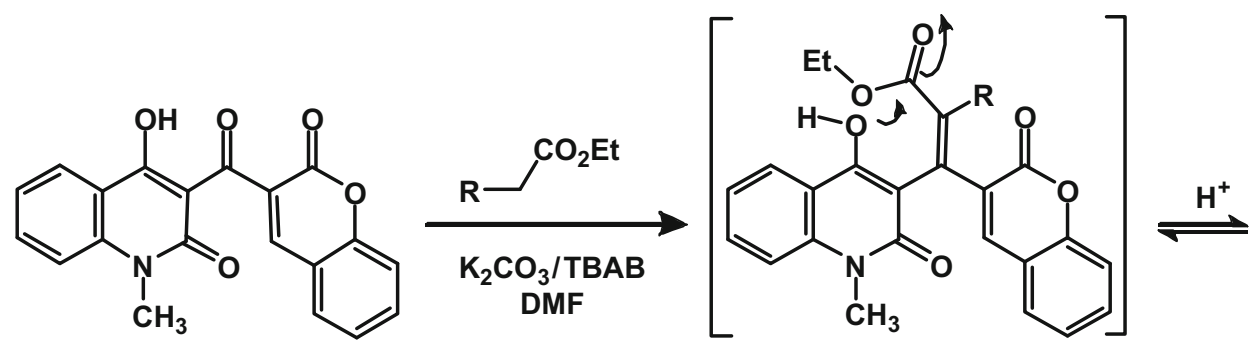

2

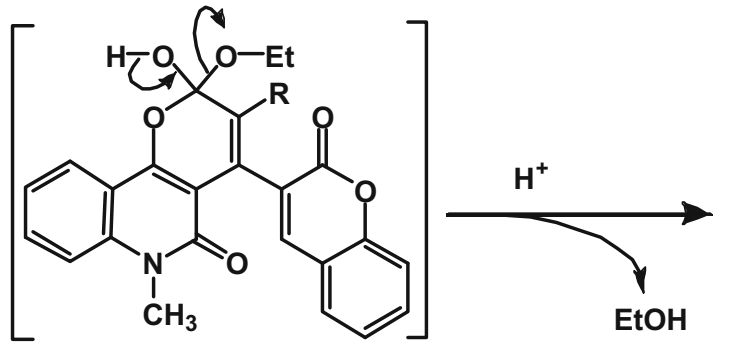

19<smiles>[R]c1c(-c2cc3ccccc3oc2=O)c2c(=O)n(C)c3ccccc3c2oc1=O</smiles>

$20 \mathrm{a}, \mathrm{R}=\mathrm{CO}_{2} \mathrm{Et}$

$20 \mathrm{~b}, \mathrm{R}=\mathrm{CN}$

Scheme 5. Formation of chromenylpyrano[3,2-c]quinoline derivatives 20a,b. 
$\alpha$-pyrone, and 2-quinolone, respectively. Mass spectrum showed a base peak at $\mathrm{m} / \mathrm{z} 144$ corresponding to 3,4dehydrocoumarin cation in addition to a peak at $\mathrm{m} / \mathrm{z}$ $175(26.3 \%)$ characteristic for 4-hydroxy-1-methyl-2quinolone cation. Under the same PTC conditions, the compound 2 was reacted with ethyl cyanoacetate,. IR spectrum of the product showed a clear evidence for the presence of a cyano group, as observed at $\tilde{v} 2203 \mathrm{~cm}^{-1}$.
Additionally, ${ }^{1} \mathrm{H}$ NMR spectrum gave no indication for the presence of $O$-ethyl protons, revealing the absence of carboxylate group. These results have led to decision that the product was the coumarinylpyranoquinoline-3carbonitrile 20b (scheme 5).

Reaction of the compound $\mathbf{2}$ with malononitrile, at the molar ratio 1:1, was carried out either under the above PTC-conditions. Characterization of the product<smiles>Cn1c(=O)c(C(=O)c2cc3ccccc3oc2=O)c(O)c2ccccc21</smiles>

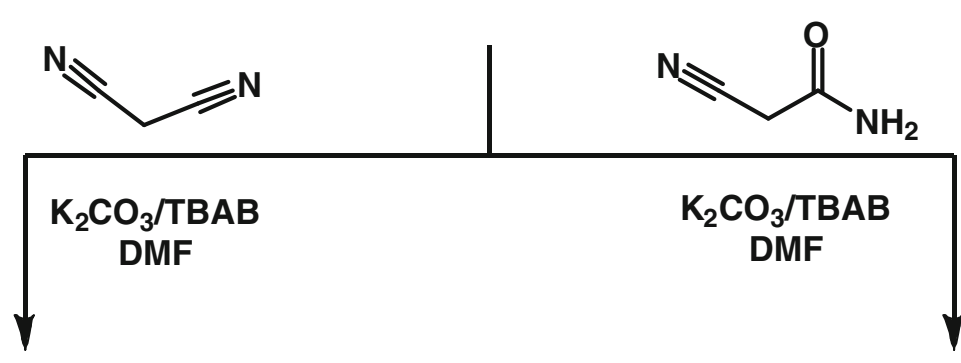<smiles></smiles><smiles></smiles><smiles>Cn1c(=O)c2c(-c3cc4ccccc4oc3=O)c(C#N)c(=N)oc2c2ccccc21</smiles>

21<smiles>CC(O)c1c(C(=C(C#N)C(N)=O)c2cc3ccccc3oc2=O)c(=O)n(C)c2ccccc12</smiles>

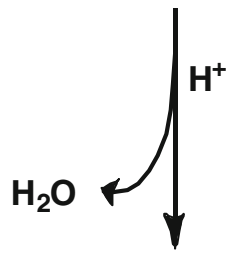<smiles>Cn1c(=O)c2c(-c3cc4ccccc4oc3=O)c(C#N)c(=O)[nH]c2c2ccccc21</smiles>

22

Scheme 6. Formation of chromenylpyrano[3,2-c]quinoline 21 and chromenylbenzonaphthyridine 22. 
satisfactorily supported that malononitrile underwent nucleophilic condensation at the chain carbonyl group, followed by an intramolecular nucleophilic addition of enolate oxygen anion to one of the two cyano functions (6-exo-dig ring closure), leading to 2-iminopyrano[3,2-c] quinoline-3-carbonitrile 21, in 84\% yield (scheme 6). ${ }^{1} \mathrm{H}$ NMR spectrum showed signal peaks at $\delta 3.70$ due to $\mathrm{N}-\mathrm{CH}_{3}$, and at $\delta 8.10$ which was attributed to $\mathrm{C} 4-\mathrm{H}$ of coumarin. In addition, a singlet signal was observed at $\delta 8.75$ due to $\mathrm{N}-\mathrm{H}$, disappeared on addition of deuterium oxide. IR spectrum exhibited vibrational bands at $\tilde{v} 3396$ due to $\mathrm{N}-\mathrm{H}, 2201$ due to $\mathrm{CN}$, 1710 due to $\mathrm{C}=\mathrm{O}$ of coumarin, and 1640 due to $\mathrm{C}=\mathrm{O}$ of quinolone. The same PTC-conditions were applied in the reaction of the compound $\mathbf{2}$ with cyanoacetamide. IR spectrum of the product showed stretching bands at $\tilde{v} 3424$ due to $\mathrm{NH}, 2198$ due to $\mathrm{C} \equiv \mathrm{N}, 1722$ due to $\mathrm{C}=\mathrm{O}$ of $\alpha$-pyrone, and $1644 \mathrm{~cm}^{-1}$ due to $\mathrm{C}=\mathrm{O}$ of $\alpha$-pyridone. ${ }^{1} \mathrm{H}$ NMR spectrum indicated the presence of an acidic proton, observed as singlet signal at $\delta 8.30$ exchangeable with deuterium, due to $\mathrm{N}-\mathrm{H}$ of naphthyridine. Consequently, the structure was deduced as 4-coumarinylbenzo[ $h][1,6]$ naphthyridine3-carbonitrile 22 (scheme 6).

\section{Conclusion}

The reaction of 4-hydroxy-1-methyl-3-[(2-oxo-2Hchromen-2-yl)carbonyl]quinoline-2(1H)-one (2) with some selected nucleophilic reagents gave new interesting polynuclear heterocyclic compounds. PTCConditions have been proved to be useful in reaction of the ketone 2 with nucleophiles, in particular $C$ nucleophiles, leading to fused polynuclear heterocycles.

\section{References}

1. Ojala T, Remes S, Haansuu P, Vuorela H, Hiltunen R, Haahtela K and Vuorela P 2000 J. Ethnopharm. 73 299
2. Mashelkar U C and Audi A A 2006 Indian J. Chem. 45B 1463

3. Vyas K B, Nimavat K S, Jani G R and Hathi M V 2009 Orbital 1183

4. Widelski J, Popova M, Graikou K, Glowniak K and Chinou I 2009 Molecules 142729

5. Manojkumar P, Ravi T K and Subbuchettiar G 2009 Acta Pharm. 59159

6. Lacy A and O'Kennedy R 2004 Current Pharm. Design 103797

7. O'Reilly R A and Kowitz P E 1967 J. Clinical Investigation 46829

8. Choure R and Pitre K S 2010 Canadian J. Chem. Eng. Technol. 17

9. Rennenberg R J M W, Varik B J V, Schurgers L J, Hamulyak K, Cate H T, T Leiner, Vermeer C, Leeuw P W D and Kroon A A 2010 Blood 1155121

10. Wagner B D 2009 Molecules 14210

11. Luan X H, Cerqueira N M F S A, Oliveira A M A G, Raposo M M M, Rodrigues L M, Coelho P and OliveiraCampos A M F 2002 Adv. Colour Sci. Technol. 518

12. Pai N R, Dubhashi D S and Pusalkar D 2010 Inter. J. Pharm. Sci. Rev. Res. 5124

13. Murugesh S, Kumar M B and Prakash G A 2011 Inter. Res. J. Pharm. 2179

14. Jampilek J, Musiol R, Pesko M, Kralova K, Vejsova M, Carroll J, Coffey A, Finster J, Tabak D, Niedbala H, Kozik V, Polanski J, Csollei J and Dohnal J 2009 Molecules 141145

15. Cheng P, Gu Q, Liu W., Zou J-F, Ou Y-Y, Luo Z-Y and Zeng J-G 2011 Molecules 167649

16. Zhong W, Liu H, Kaller M R, Henley C, Magal E, Nguyen T, Osslund T D, Powers D, Rzasa R M, Wang H-L, Wang W, Xiong X, Zhang J and Norman M H 2007 Bioorg. Med. Chem. Lett. 175384

17. Abass M and Mostafa B B 2005 Bioorg. Med. Chem. 13 6133

18. El-Shennawy A M, Mohamed A H and Abass M 2007 Medscape Gen. Med. 915

19. El-Shennawy A M, Hammam O A, Abass M, and Ali E 2008 New Egypt. J. Med. 39573

20. El-Shennawy A M, Abass M and Mostafa A 2009 New Egypt. J. Med. 40308

21. Abass M, Mohamed E A, Ismail M M and Mayas A S 2011 European J. Chem. 2378

22. Abass M and Othman E S 2001 Synth. Commun. 31 3361

23. Abass M 2000 Synth. Commun. 302735 